


\title{
A EXPERIÊNCIA DA \\ AUTOGESTÃO EM \\ IPATINGA: UMA BUSCA \\ PELO CONCEITO'
}

THE SELF-MANAGEMENT EXPERIENCE IN IPATINGA: A SEARCH BYTHE CONCEPT

\section{Alfio Conti ${ }^{2}$}

\section{Resumo}

Neste artigo, é tratado, em um primeiro momento, o conceito de mutirão em autogestão para produção de moradias populares, suas origens, características e potencialidades; em um segundo momento, é abordado, brevemente, a experiência dos mutirões em autogestão desenvolvida pela Prefeitura de Ipatinga-MG, de 1989 a 1999, dando ênfase à avaliação crítica desta em termos de resultados, alcances e contribuições para futuros empreendimentos e experiências desse tipo.

Palavras-chave: Autogestão; Habitação popular.

\begin{abstract}
This paper is about, at first, the concept of self-management task force to produce popular housing, its origins and characteristics and potential. In a second moment, is treated, briefly, the experience of the task force in self-management developed by the Ipatinga city hall, Minas Gerais, 1989-1999, emphasizing its critical evaluation in terms of results, achievements and contributions to future endeavors and this kind of experiences.
\end{abstract}

Keywords: self-management, social housing. 